\title{
Micro-morphological descriptions on Cenchrus species from Rajasthan (India)
}

Sunita Arora and Ganesh Kumar

Department of Botany, Jai Narain Vyas University, Jodhpur (Raj.), India.

Received: 2/14/2018; Revised: 2/23/2018; Accepted: 2/27/2018

\begin{abstract}
Present investigation was carried out to screen micro-morphological features of Cenchrus species $\left(\mathrm{C}_{4}\right.$ plant) belonging to family Poaceae. This is an important medicinal, fodder as well as crop plant and traditionally used as famine food during drought. It is best suited for desert environmental conditions. In extreme conditions when food is in scarce, seeds of this grass are consumed by tribals. The microscopical illustrations revealed several interesting features i.e. presence of cuticle, bulliform cells, trichomes, lysigenous cavity, more amount of chlorenchyma, Y- shaped vascular bundles, double layered bundle sheath, large vessels and starch grains that support its assimilation efficacy and survival in typical conditions of Thar Desert. This study helps in referential identification, authentication, standardization and detection of adaptation strategies to understand biology of this plant.
\end{abstract}

Key words: Buffel grass, Bulliforms cells, Bundle sheath, Chlorenchyma, $\mathrm{C}_{4}$ plants, Monocot, Kranz anatomy, Poaceae.

\section{Introduction}

The grass family is of greater importance to humanity than any other family of flowering plants. The edible grains of cultivated grasses or cereals are the basic foods of civilization with wheat, rice and corn that are most extensively grown of all food crops. Other important cereals are barley, sorghum, oats, millet and rye; most of them are among the top 25 food crops (Levetin and Mcmahon, 2008). In addition, grasses form an important part of the urban and suburban landscape in much of the world. Members of the family also are ecological dominants, covering approximately $20 \%$ of the earth's land surface (Shantz, 1954). There are approximately 600 genera and 8,500 species of grasses found throughout the world making the grass family one of the largest and most widely distributed plant families. Grasses are the dominant plants in prairies and savannas but can also be found wherever plants can grow or under a wide variety of environmental conditions i.e. from arctic marshes to tropical swamps. In fact $25 \%$ of the world's vegetation belongs to the grass family.

Panicoideae includes 3,560 species in 12 tribes. The species are predominantly distributed in tropical to warm-temperate habitats with summer precipitation and in tropical forests and savannas. Important genera include Zea mays L. (corn or mays), Saccharum officinarum L. (sugarcane), Sorghum bicolor L. (sorghum), Cenchrus L., Panicum L. and Setaria P. Beauv. The tribe Paniceae R.Br. (Subfamily Panicoideae) includes 84 genera and nearly 1500 species of grasses (Morrone et al., 2012; Soreng et al., 2015). Members belonging to this tribe exist mainly

\section{*Corresponding Author:}

Prof. Sunita Arora,

Department of Botany,

Jai Narain Vyas University,

Jodhpur (Raj.), India.

E-mail: jnvusunitarora@gmail.com in tropical and subtropical areas around the globe but also have limited distributions in cooler climates (Morrone et al., 2012.

Cenchrus is an apomicitic grass species as it is well adapted to a wide range of soil types and grown as rain fed and as an irrigated crop for forage (Geetha, 2001). Cenchrus ciliaris L. (Buffel grass) is grown widely in tropical and sub-tropical arid rangelands around the globe because of its high drought tolerance and capacity to withstand heavy grazing. Buffel grass has the ability to rapidly invade the surrounding environment (Marshall et al., 2012). Cenchrus setigerus Vahl, commonly known as "Bird wood grass" is a highly nutritious grass treated as an excellent pasture for animal husbandry (Arora and Kumar, 2018). Cenchrus biflorus, commonly known as "Indian Sandbur" or "Bhurat" is very much used at the time of food scarcity as "famine food". The grains of it pounded and mixed with Bajra flour to make a roti known as "Sogra" consumed by villagers and local persons (Arora et al., 2017)

Decoction of roots of Buffel grass is given to children suffering from intestinal worms (Katewa et al., 2001). C. ciliaris has also been used as folk remedies for kidney pain, tumors, sores and wounds. It can be used as an anodyne (pain reliever), lactogogue (increased milk flow) and diuretic and as an emollient. Cenchrus is an important pasture grass in the tropics mainly because of its low cost of establishment, high yields with more nutrients, tolerance to drought conditions and crop pests and its ability to withstand heavy grazing and 
trampling by livestock. It is now being commercialized for its ability to increase the flow of milk in cattle and give a sleek and glossy appearance to their coats (Duke, 1983). In present study an effort has been made to describe comparative micro-morphological features of three different species of Cenchrus.

\section{Materials and Methods}

Collection and Identification of plant samples Fresh, disease free plants of Buffel grass, Bird wood grass and Indian Sandbur grass were collected from Barmer and Jodhpur districts of Rajasthan (India) during rainy season. Preliminary specimen identification and authentication was done by Dr. C.S. Purohit (Scientist, Botanical Survey of India, Jodhpur) and 'The Flora of the Indian Desert' (Bhandari, 1978) and 'Flora of Rajasthan' (Shetty and Singh, 1993) was referred for confirm recognition.

\section{Sectioning and Staining Procedure}

Material for anatomical studies were obtained from the mature upper parts of root, stem and leaves of the grasses; The material was fixed in formalin acetic alcohol, a mixture of 5 parts formalin, 5 parts acetic acid and 90 parts $70 \%$ ethyl alcohol(FAA). Thin sections of various plant parts were cut using commercial tools. Fine sections were double stained using Safranin (1\% solution in 50\% alcohol) and
Fast green ( $1 \%$ solution in hydro-alcohol), Glycerine was used for making temporary mounts. Microscopic observations were carried out by using Olympus BX-60 microscope with 10X, 40X and $100 \mathrm{X}$ objectives. The staining results were remarkably good. Photomicrographs were prepared with Sony HD (1920x1080/50i) digital camera. Special identifying features of the plant parts were studied and identified.

\section{Results and Discussion}

Root

\section{Cenchrus ciliaris}

Epiblema is outermost layer consists of compactly arranged, polygonal, parenchymatous cells without intercellular space with thick cuticle and unicellular hairs. Cortex is multilayered, on maturity few outer layers of cortex turn mechanical (suberized) and replaces epiblema to form multilayered exodermis. Endodermis is uniseriate with casperian strips present on tangential wall. Pericycle is uniseriate with thick wall. Vascular elements are radial, collateral, closed, polyarch and exarch. Metaxylem elements are large, circular/oval. Xylems possess large vessels and more amounts of tracheids. Phloems possess companion cells and parenchyma. Ground tissue is large, parenchymatous with intercellular spaces containing starch grains in it (Fig. 1.a).

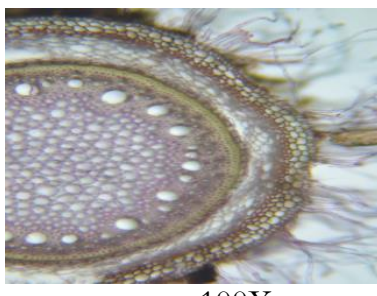

$100 \mathrm{X}$

Fig.1a. T.S. of Cenchrus ciliaris root

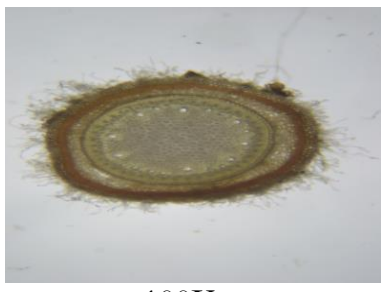

100X

Fig.1b. T.S. of Cenchrus setigerus root

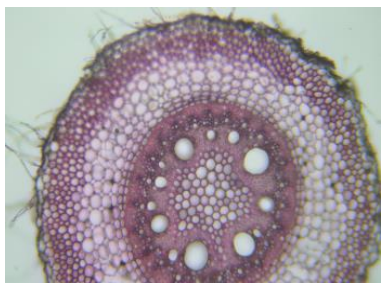

400X

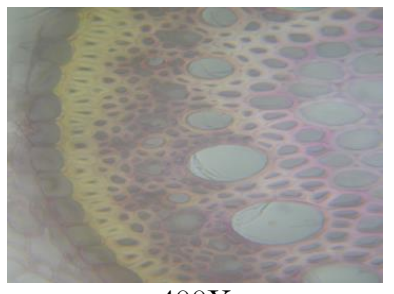

$400 \mathrm{X}$

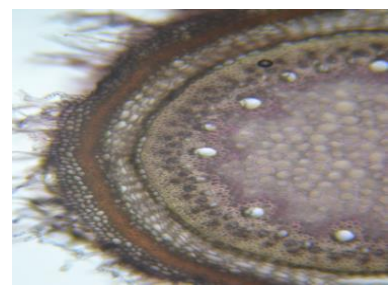

400X

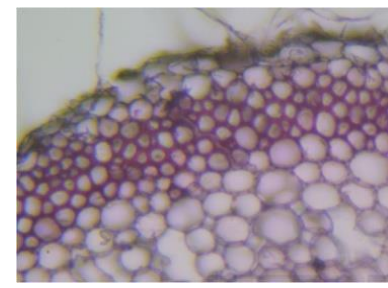

400X

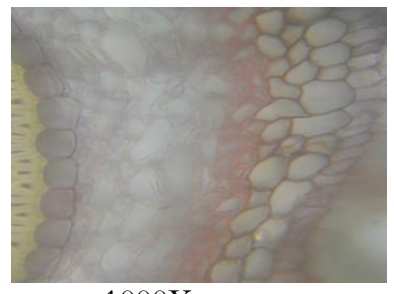

1000X

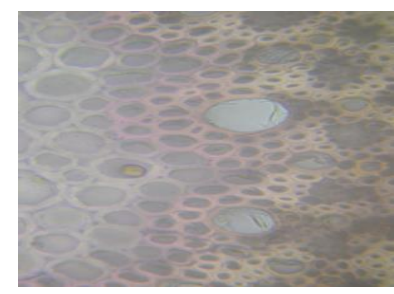

1000X

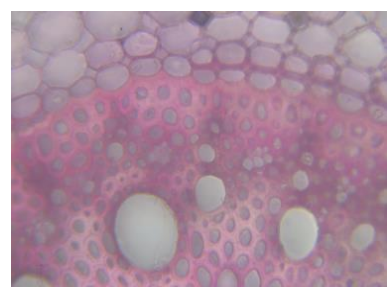

400X

Fig.1c. T.S. of Cenchrus biflorus root 


\section{Cenchrus setigerus}

Anatomical feactures are almost similiar to Cenchrus ciliaris. Difference lies only in width of pericycle that is more prominent. Exodermis is clearly defined, circular and thick ring. Metaxylem elements are comparatively small (Fig. 1.b).

\section{Cenchrus biflorus}

Exodermis is wider than Cenchrus ciliaris and Cencbrus setigerus. Cortex is also wider and contains starch grains. At certain regions, cortical cells pierce endodermis and pericycle. Metaxylem cells are heterogenous in size. Ground tissue is comparatively lesser in amount (Fig. 1.c).

\section{Stem}

\section{Cenchrus ciliaris}

Epidermis is uniseriate and cuticularized. Cortex is made up of chlorenchyma and collenchyma that is followed by 2-3 layerd sclerenchyma. Some vascular bundles are embedded in hypodermal region.
Vascular bundles are embedded distributed in ground tissue that is Parenchymatous, bundles are Y-shaped, collateral and closed. Metaxylem is pitted and is present in form 2 large vessels making arms of Y. Protoxylem is at the base, smaller associated with lysigenous cavity, xylem possess parenchyma, tracheids and vessels. Phloems possess companion cells and sieve tubes, some upper cells of phloem may get crushed. The complete bundle remains enclosed in a sclerenchymatous bundle sheath (Fig.2a).

\section{Cenchrus setigerus}

There is no difference except in the cortex that contains more chlorenchyma and ground tissue that contains some collenchymatous cells in the center (Fig.2b).

\section{Cenchrus biflorus}

Cortex is parenchymatous and sclerenchymatous, amount of chlorenchyma is least (Fig.2c).

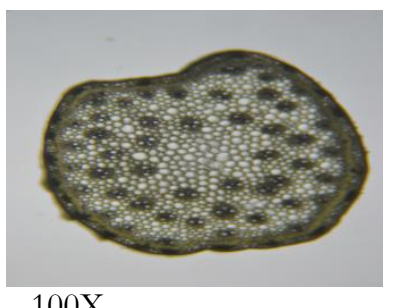

100X

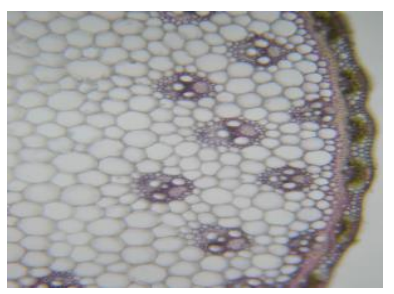

$400 \mathrm{X}$

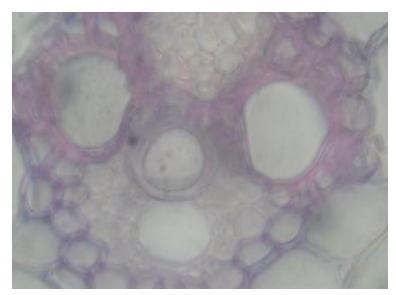

1000X

Fig.2a. T.S. of Cenchrus ciliaris stem
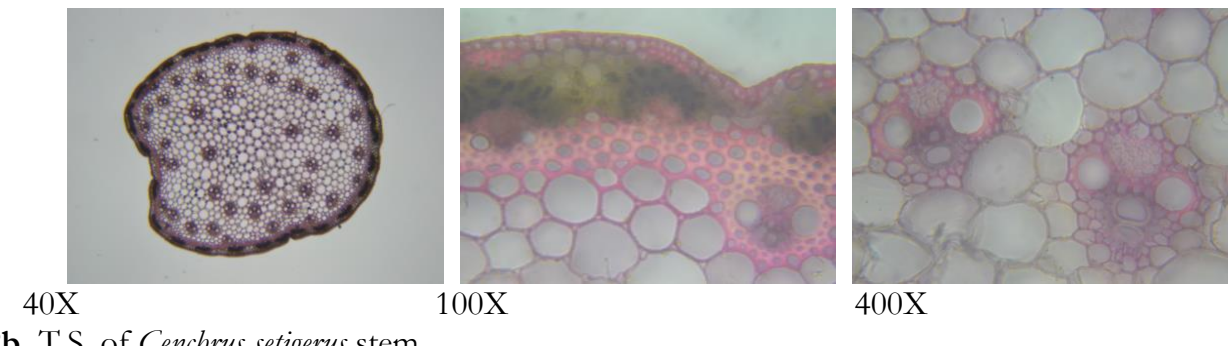

Fig.2b. T.S. of Cenchrus setigerus stem

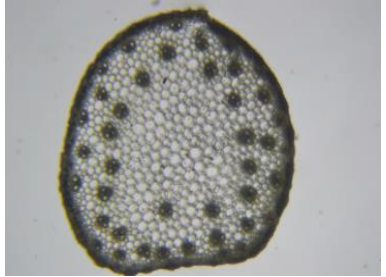

40X

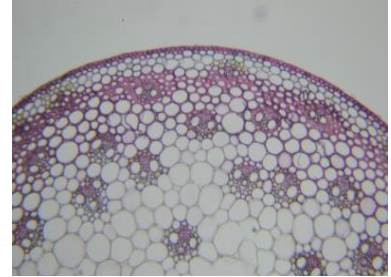

100X

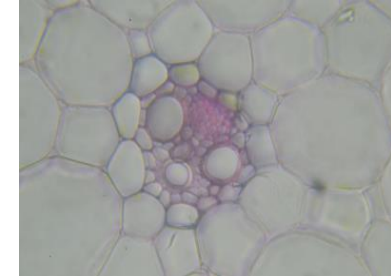

400X

Fig.2c. T.S. of Cenchrus biflorus ste

\section{Leaf}

\section{Cenchrus ciliaris}

Leaf shows ridges and furrows throughout but they are more prominent on upper side. Epidermis is single layered, cuticularized with unicellular trichomes on both sides. Bulliforms cells are more prominent in groove region of upper epidermis. Vascular bundles are distributed throughout. Xylem is more prominent and shows clear differentiation in large vascular bundles. Amount of parenchyma is more in midrib region. Midrib bundle is present towards lower epidermis with bi-layered bundle sheath that is rich with chlorenchyma. Metaxylem vessels are large; protoxylem vessels smaller, facing upper epidermis and xylem possesses tracheids and vessels. Phloem is present towards lower epidermis 
and contains companion cells and sieve tubes. Remaining small bundles shows xylem on upper side and phloem towards lower side, these bundles remains encircled with bi-layered bundle sheath but the inner one is parenchymatous and outer is chlorenchymatous. All the vascular bundles are conjoint, collateral and closed (Fig. 3a).

\section{Cenchrus setigerus}

Almost similar except bulliforms cells that are less in amount and vascular bundles are more close to each other. Sclerenchyma lies below the bundles and less in amount (Fig. 3b).

\section{Cenchrus biflorus}

Show almost similar features except enormous trichomes that remain present on both the epidermal surface. Xylem shows mores vessels (Fig. 3c).

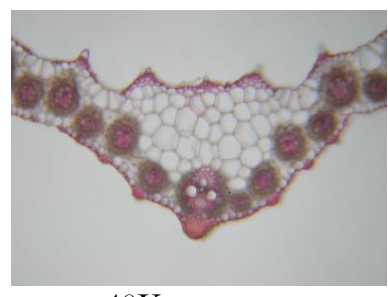

$40 \mathrm{X}$

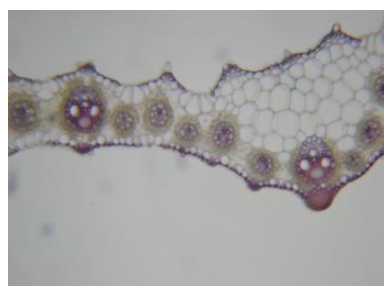

100X

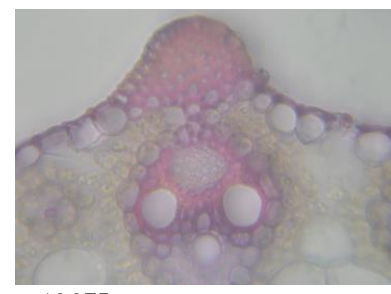

400X

Fig.3a. T.S. of leaf of Cenchrus ciliaris

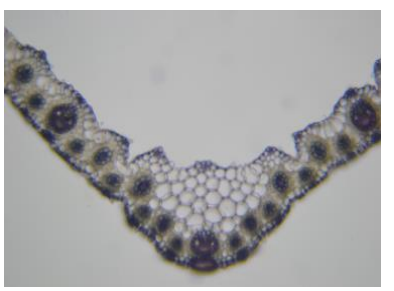

$40 \mathrm{X}$

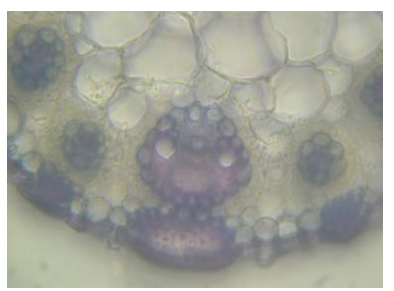

100X

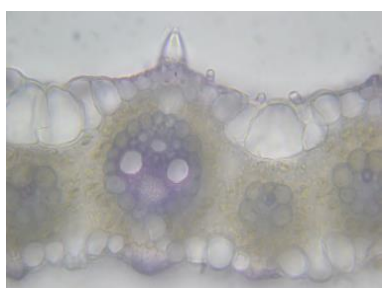

$100 \mathrm{X}$

Fig.3b. T.S. of leaf Cenchrus setigerus

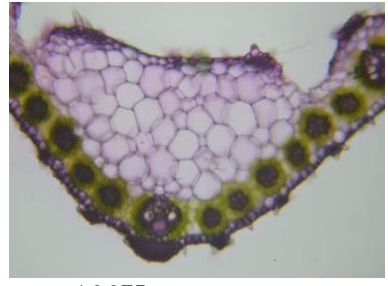

$100 \mathrm{X}$

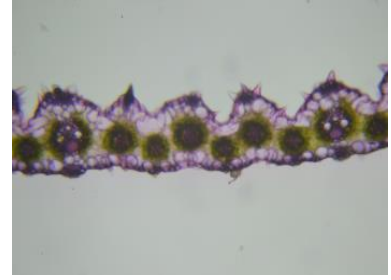

$400 \mathrm{X}$

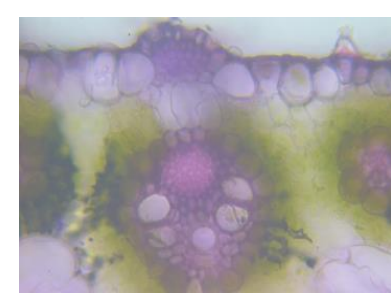

$400 \mathrm{X}$

Fig.3c. T.S. of Cenchrus biflorus leaf

\section{Conclusion}

Taxonomic disputes can easily be resolved using anatomical parameters. All the species under investigation reveal least differences suggesting their status in similar tribe. Presence of bulliform cells in grooves, large vessels and extended bundle sheath providing mechanical support and reduced stomata supports its existence in desert climate. This plant is medicinally also useful as reported earlier by same author. Further research may open more scope for its future use.

\section{Acknowledgement}

The authors are thankful to the CAS, Department of Botany, J.N.Vyas University, Jodhpur (Rajasthan) for providing infrastructure and technical support.We are also thankful to Institute of Herbal Heritage, Jodhpur for assisting in microscopic assessment.

\section{References}

1. Levetin-McMahon. Plants and society. $5^{\text {th }}$ edition, The McGraw-Hill Companies (2008).

2. Shantz HL. The place of grasslands in the earth's cover of vegetation. Ecology, 35 (1954) pp. 143-145.

3. Morrone $\mathrm{O}$, Aagesen L, Scataglini MA, Salariato DL, Denham SS, Chemisquy MA, Sede SM, Giussani LM, Kellogg EA and Zuloaga FO. Phylogeny of the Paniceae (Poaceae: Panicoideae): Integrating plastid DNA sequences and morphology into a new classification. Cladistics, 28.4 (2012) pp. 333 356.

4. Soreng RJ, Peterson PM, Romaschenko K, Davidse G, Zuloaga FO, Judziewicz EJ, 
Filgueiras TS, Davis JI and Morrone O. A worldwide phylogenetic classification of the Poaceae (Gramineae). Journal of Systematics and Evolution, 53.2 (2015) pp. 117 - 137.

5. Geetha R. Studies on seed production, processing, dormancy and storage in Blou Buffel (Cenchrus glaucus) cv. CO1. Ph.D. Thesis, Tamilnadu Agricultural University, Coimbatore (2001).

6. Marshall VM, Lewis MM and Ostendorf B. Buffel grass (Cenchrus ciliaris) as an invader and threat to biodiversity in arid environments: A review. Journal of Arid Environments, 78 (2012) pp. 1-12.

7. Arora S and Kumar G. Phytochemical screening of root, stem and leaves of Cenchrus biflorus Roxb. Journal of Pharmacognosy \& Phytocemistry, 7.1 (2018) pp. 1445-1450.

8. Arora S, Kumar G and Meena S. GC-MS analysis of bioactive compounds from the whole plant hexane extract of Cenchrus setigerus Vahl. Pharma Science Monitor, 8.4 (2017) pp. 137146.
9. Katewa SS, Guria BD and Jain A. Ethnomedicinal and obnoxious grasses of Rajasthan, India. Journal of Ethnopharmacology, 76.3 (2001) pp. 293-297.

10. Duke JA. Cenchrus ciliaris L. Handbook of Energy crops, unpublished, Center for New Crops \& Plants Products, Purdue University, Indiana (1983). or http://www.hort/puedue/duke_energy/Cench rus_ciliaris.html.

11. Bhandari MM. Flora of Indian Desert, $2^{\text {nd }}$ edition. MPS Repros, Jodhpur. (1978).

12. Shetty BV, Singh V. Flora of Rajasthan, (Botanical Survey of India) KolKata. (1993).

\section{Cite this article as:}

Sunita Arora and Ganesh Kumar. Micromorphological descriptions on Cenchrus species from Rajasthan (India). Annals of Plant Sciences 7.3 (2018) pp. 2141-2145.

do http://dx.doi.org/10.21746/aps.2018.7.3.8

Source of support: CAS, Department of Botany, J.N.Vyas University, Jodhpur (Rajasthan), India.

Conflict of interest: Nil 